light of the inability of most of the antibiotics that are used for the treatment of meningococcal infections to serve as prophylactic agents. We performed throat cultures on various populations in Cairo, Egypt, ${ }^{2}$ where group A meningococcal disease is endemic. Most cases occur in school-age children, a population that we found had a $3.8 \%$ carrier rate. Only one of the 58 patients positive by culture of cerebrospinal fluid for agents other than Neisseria was a group A meningococcal carrier. Group A meningococci, however, were isolated from $55 \%$ of 380 patients who were culture positive for this organism and from $30^{\circ} \%$ of 46 patients who were culture negative but shown to have meningococcal meningitis by stain or detection of specific antigen in cerebrospinal fluid.

We therefore concur that culture of patients' throats can contribute to laboratory diagnosis. Jewes et al argued that culturing the throats of contacts was not useful for diagnosis due to a lack of correlation in serotype between isolates from contacts and index cases. ${ }^{3}$ We found that the rate of group A carriage in the contacts of group A patients $(15 \%)$ was four times that in school children, suggesting that monitoring this population could also be helpful in diagnosis of cases. JE SIPPEL Mercer University, School of Medcine,
Macon, Georgia 31207 NI GIRGIS Naval Medical Research Unit No 3, clo US Embassy, Cairo, Egypt

1 Cartwright KAV, Jones DM. Investigation of meningococcal disease. J Clin Pathol 1989; 42:634-9.

2 Sippel JE, Girgis NI. Meningocccal infection in Egypt: Laboratory findings in meningitis patients and their prevalence of pharyngeal infection in patients and contacts. Am J Trop Med Hyg 1978;27:980-5.

3 Jewes L, Norman P, McKendrick MW. Value of throat swabs in meningococcal meningitis. $J$ Clin Pathol 1989;42:1229.

\section{Lamina propria mast cells in ulcerative collitis}

We were interested to see the response from Dr Crow to our paper on mast cells and eosinophils in Asian and Caucasian patients with ulcerative colitis' and would agree that formalin fixed material is not ideally suited to demonstration of mast cells. In our experience, however, carefully controlled use of the Astra blue technique is at least generally acceptable in this context. ${ }^{2-4}$ It should, of course, be remembered that our study was of a comparative rather than absolute enumerative type and the probable lowering of counts for both groups would therefore still clearly show differences between them as there is no reason to presume that staining would differ between the groups.

It might be of interest to run other techniques on our tissues, and if time permits we will consider this.

GFA BENFIELD RL BRYAN
J CROCKER Departments of Respiratory Medicine and Histopathology, East Birmingham Hospital, Bordesley Green East, Birmingham B9 5ST

1 Benfield GFA, Bryan R, Crocker J. Lamina propria eosinohils and mast cells in ulcerative colitis: comparison between Asians and Caucasians. J Clin Pathol 1990;43:27-31.
2 Crocker J, Smith PJ. A quantitative study of mast cells in Hodgkin's disease. J Clin Pathol 1984;37:519-22.

3 Crocker J, Smith PJ. Mast cells in nonHodgkin's lymphomas: a quantitative study. $J$ Clin Pathol 1987;40:470.

4 Jackson N, Burt D, Crocker J, Boughton B. Skin mast cells in polycythaemia vera: relationship to the pathogenesis and treatment of pruritus. Br J Dermatol 1987;116:21-9.

\section{Dr Crow comments}

Benfield et al found that there was no significant difference in the numbers of rectal mucosal mast cells between groups of Asian and Caucasian patients with ulcerative colitis. Unfortunately, the Astra blue technique used to stain the mast cells in this case would seriously underestimate the numbers of such cells in intestinal mucosa fixed in formolsaline $^{2}$ and any differences which might be present woud be masked. If there is only formalin fixed material available for study then the long (five to seven day) toluidine blue or trypsin toluidine blue techniques ${ }^{3}$ will at least partly overcome the blockage to staining induced by formalin and will give a more realistic count. Evidence from other tissues, however, ${ }^{4}$ suggests that fixation in basic lead acetate, isotonic formol acetic acid, or Carnoy's fixative followed by long toluidine blue staining will show up even more mast cells and hence even this staining technique must be regarded as doubtful in formalinfixed tissues unless it has been validated against one of the mast cell fixatives mentioned, for the tissue in question.

1 Blaies DM, Williams JF. A simplified method for staining mast cells with astra blue. Stain Technol 1981;56:91-4.

2 Strobel S, Miller HRP, Ferguson A. Human intestinal mast cells: evaluation of fixation and staining techniques. $J$ Clin Pathot 1981 34:851-8.

3 Wingren U, Enerbäck L. Mucosal mast cells of the rat intestine: a re-evaluation of fixation and staining properties, with special reference to protein blocking and solubilty of the granular protein blocking and solubilty of the granular
glycosaminoglycan. Histochem $J$ 1983;15: glycosamin

4 Crow J, More L, Howe S. The mast cells of the human uterus. APMIS 1988;96:921-6.

\section{BOOK REVIEWS}

Essential Histopathology. PR Millard. (Pp 326; £18.50.) Blackwell Scientific Publications. 1989. ISBN 0-632-02238-8.

Peter Millard's book is eye-catching and has a text clearly laid out and supported by largely excellent photographs with splendid diagrams and line drawings. Many pathology books present the subject in a too detailed and boring manner but this is clearly not Millard's style. The first impression, therefore, is that this book is clearly going to be a hit. Reluctantly, after using it for several weeks I think it a splendid effort but, nevertheless, still a miss.
Dr Millard has attempted to present the histopathology an undergraduate requires without unduly overloading him and he has been rightly selective and brief. Sometimes he succeeds in presenting a lucid picture of his target - for example, diabetes mellitus. At other times his brevity fails as in his attempt to unify the malignancies in the gut. He omits any account of bone and joint pathology yet presents two chapters on tissue responses and on tumours. Although these are elegantly illustrated, they are too superficial to be of value to final students and in any case fit better into a general pathology text book.

I hope my students read this book but only as a supplement after buying a larger text which puts more emphasis on mechanisms rather than appearances of disease. The attractive format and the relatively few pages (235) of essential histopathology may well seduce students into buying it at its relatively modest price. Only when they get it home will they find that Dr Millard's publishers have let him down with no less than eight incorrectly printed figures. In the longer term as the examination looms its other deficits will make themselves felt.

"Hit" or "miss", it all depends where you judge the bull to be. My criticisms may reflect not Millard's aim but where he judges the target. With a bit of retargeting, the style and presentation of this book could well make a winner in future editions. At any rate it is a good attempt at presenting pathology in a vital manner which will catch the student's eye, and as such deserves applause.

G SLAVIN

Pathology of the Stomach and Duodenum. H Rotterdam, HT Enterline. (Pp 320; DM 248.) Springer. 1989. ISBN 0540-96823-7.

This book, by two experienced American gastrointestinal pathologists, sets out to offer information on all aspects of gastric and duodenal disease including historical, epidemiological, clinical, and pathophysiological data, with the emphasis on diagnostic gross and microscopic pathology. The coupling of stomach with duodenum was decided because of the common pathophysiology of some gastric and duodenal diseases, such as peptic ulcer disease. The exclusion of oesophageal disease seems somewhat arbitrary, therefore, as the principle of common pathophysiology would also seem to apply. The participation by one of the authors in a previously published monograph on this subject is the probable explanation.

The book succeeds in some of its aims and in particular the chapters on anomalies, hyperplasias, and benign epithelial tumours and carcinoid (neuroendocrine) tumours were very good and well referenced. On the debit side there was little current information on Campylobacter pylori and the discussion of malignant lymphomas was largely on the basis of the Rappaport classification. There were a number of typographical errors and the quality of many of the illustrations, particularly the photomicrographs, was poor.

In summary, while good in parts, this book does not stand out in a competitive marketplace. It is also expensive.

DW DAY 